\title{
Effect of Aubergine (Solanum melongena) on Serum and Hepatic Cholesterol and Triglycerides in Rats
}

\author{
Marcelo E. Silva, Rinaldo C. Santos ${ }^{*}$, Maureen C. O'Leary ${ }^{1}$ and Ronald S.Santos ${ }^{2}$. \\ Depto de Alimentos, Escola de Nutrição, Universidade Federal de Ouro Preto, 35400-000, Ouro Preto, MG.(1) \\ IAESTE/University of Cork, Ireland.(2) PET- Nutrição/UFOP
}

\begin{abstract}
The present work reports the effect of aubergine extract on serum and hepatic cholesterol and triglycerides levels in adult rats. Fisher rats were divided into three groups: the first one received a normolipidic diet and water, serving as a control; the other two received a hypercholesterolaemic diet with $30 \%$ vegetable oil and $1 \%$ cholesterol, one of these being given water while the other was given an aubergine extract. After 28 days the animals were sacrificed and serum and hepatic cholesterol and triglycerides levels were assessed. The obtained results indicated that under the experimental conditions employed, the aubergine extract increased serum and decreased hepatic cholesterol and had little or no effect on both serum and hepatic triglycerides.
\end{abstract}

Key words: aubergine, eggplant, Solanum melongena, serum cholesterol, hepatic cholesterol

\section{INTRODUCTION}

Hypercholesterolaemia is considered a serious health problem. There are reports that the consumption of infusions of plants such as artichoke (Cynara scolymus) and rosemary (Rosmarinus officinalis) is capable of reducing plasma cholesterol levels (Cortella and Pochettino, 1997). Another plant that has been cited as having this property is aubergine (Solanum melongena). Kritchevsky et al. (1975), working with radioactively labeled carbon, concluded that aubergine infusion lowers serum cholesterol in rabbits, through its effect of diminishing dietary cholesterol absortion. Mitschek (1975) studied histopathologically rabbits treated with aubergine extract for 4 or 12 weeks and observed improvement in some of the histological parameters, although others were not altered. There are reports describing the mechanism of action of the plant in the development of ateromas induced by cholesterol in rabbits (Mitschek, 1974; Autobock and Mitschek, 1974; Mitschek, 1975 ). Kayamori and Igarashi (1994) tested the effect of nasunin, an antocianin extracted form aubergine, and of delfidin (its aglicone) on serum cholesterol level in rats and concluded that both contributed to the reduction and the elevation, respectively of total serum cholesterol and HDL-cholesterol, in part due to the inhibition of intestinal absortion of cholesterol and bile acids.

The present work aimed at investigating the effects of aubergine extract on serum and hepatic cholesterol in rats, stressing that what is popularly called aubergine infusion is actually a cold extract since, according to popular belief, heating diminishes the properties of the plant.

\section{MATERIALS AND METHODS}

Animals and experimental groups: Fourmonth old Fisher rats were used, which were distributed randomly among the experimental groups as follows: six in the control (C), six in the hypercholesterolaemic plus water (HW) and twelve in the hypercholesterolaemic plus aubergine extract (HA). Animals were kept in individual cages, under controlled temperature, humidity and illumination, receiving water or aubergine extract and ration "ad libitum" for 28 days.

Aubergine extract: Aubergine extract was freshly prepared by cutting one $\mathrm{Kg}$ of previously washed vegetable into cubes and keeping them in two $\mathrm{L}$ of water overnight.

\footnotetext{
* Author for correspondence
} 
Experimental protocol: Animals of group C received a normolipidic diet (control diet) while those of groups HW and HA were fed a hypercholesterolaemic diet (containing 1,0\% cholesterol and $30 \%$ soybean oil). The composition of the diets is given in Table 1. Diet ingestion and weight of the animals were recorded weekly. At the end of the experiment (28 days), animals were sacrificed and liver and serum were removed for determination of hepatic and serum lipids.

Table 1: Composition of the diets (g)

\begin{tabular}{ccc}
\hline Ingredients & Control diet (g) & $\begin{array}{c}\text { Hypercolesterolae } \\
\text { mic diet (g) }\end{array}$ \\
\hline Casein & 120 & 120 \\
Mineral mixture & 50 & 50 \\
Vitamin mixture & 10 & 10 \\
Celulose & 10 & 10 \\
Soybean oil & 80 & 300 \\
Cholesterol & 0 & 10 \\
Cholin & 4 & 4 \\
Corn starch & 726 & 496 \\
\hline
\end{tabular}

Serum lipids assessment: After anesthesizing the animals and opening the abdome, the intestine was removed and the abdominal aorta artery was sectioned. Blood was taken into a centrifuge tube and centrifuged at $3000 \mathrm{~g}$ for 15 minutes under refrigeration. Cholesterol and tryglycerides were then measured (Henry et al., 1974; Tonks, 1970).
Hepatic lipids assessment: Livers removed from the animals were dried in an air draft oven at $100^{\circ} \mathrm{C}$ for $24 \mathrm{~h}$, ground, weighed and then extracted under reflux with sulfuric ether in a Sohxlet apparatus for eight $\mathrm{h}$. Cholesterol and triglycerides were determined in the ether extracts after evaporation of the solvent, by the same methods cited above.

Statistical analysis: Analysis of variance of the results was done using the "EPISTAT" software.

\section{RESULTS AND DISCUSSION}

Tables 2 and 3 show respectively diet ingestion and weight gain of the animals of the three groups during the experiment. It could be observed that the animals did not present significant differences in diet ingestion, what should be expected since they were adult animals and thus with higher capacity of adaptation to diet modifications. When the whole experimental period was considered, there were no significant differences in the weight gain among the groups, what was equally expected, due to the fact that food consumption was statistically similar. On the other hand, there was a difference in the energy content of the control diet in relation to the hypercholesterolaemic ones, with these being $23 \%$ higher. We believe that this difference was partially compensated by higher food ingestion in the control group, although without statistical significance.

Table 2: Ingestion of diet (g)by animals of groups control (C) and hypercholesterolaemic plus water (HW) or aubergine extract (HA); mean \pm standard deviaton*.

\begin{tabular}{lcccccc}
\hline & $\mathrm{N}$ & $1^{\text {st }}$ week & $2^{\text {nd }}$ week & $3^{\text {rd }}$ week & $4^{\text {th }}$ week & Total \\
\hline Group C & 6 & $76,5 \pm 37,1 \mathrm{a}$ & $108,2 \pm 29,4 \mathrm{a}$ & $99,1 \pm 17,8 \mathrm{a}$ & $48,4 \pm 22,9 \mathrm{a}$ & $332,3 \pm 71,1 \mathrm{a}$ \\
Group HW & 6 & $67,0 \pm 30,2 \mathrm{a}$ & $84,7 \pm 26,0 \mathrm{a}$ & $73,2 \pm 24,4 \mathrm{a}$ & $50,4 \pm 20,7 \mathrm{a}$ & $283,4 \pm 49,6 \mathrm{a}$ \\
Group HA & 12 & $72,8 \pm 29,4 \mathrm{a}$ & $84,1 \pm 49,9 \mathrm{a}$ & $87,1 \pm 14,4 \mathrm{a}$ & $57,0 \pm 29,5 \mathrm{a}$ & $302,3 \pm 57,3 \mathrm{a}$ \\
\hline
\end{tabular}

* Means followed by the same letter in the same column are not statistically different $(\mathrm{P}<0,05)$.

$\mathrm{N}=$ number of animals 
Table 3: Weight gain (g) by animals of groups control $(\mathrm{C})$ and hypercholesterolaemic plus water (HW) or aubergine extract (HA); mean \pm standard deviation*.

\begin{tabular}{ccccccc}
\hline & $\mathrm{N}$ & Initial & $1^{\text {st }}$ week & $2^{\text {nd }}$ week & $3^{\text {rd }}$ week & $4^{\text {th }}$ week \\
\hline Group C & 6 & $261,8 \pm 25,8 \mathrm{a}$ & $251,6 \pm 26,1 \mathrm{a}$ & $258,3 \pm 31,2 \mathrm{a}$ & $267,4 \pm 31,9 \mathrm{a}$ & $273,0 \pm 28,7 \mathrm{a}$ \\
Group HW & 6 & $264,5 \pm 35,8 \mathrm{a}$ & $252,8 \pm 19,5 \mathrm{a}$ & $269,3 \pm 29,6 \mathrm{a}$ & $271,9 \pm 27,9 \mathrm{a}$ & $279,7 \pm 36,1 \mathrm{a}$ \\
Group HA & 12 & $261,8 \pm 24,7 \mathrm{a}$ & $262,9 \pm 13,6 \mathrm{a}$ & $274,9 \pm 28,3 \mathrm{a}$ & $283,3 \pm 27,2 \mathrm{a}$ & $285,6 \pm 35,5 \mathrm{a}$ \\
\hline
\end{tabular}

* Means followed by the same letter in the same column are not statistically different $(\mathrm{P}<0,05)$.

Another marked difference among the groups was observed in liver weight (Table 4); animals of group $\mathrm{C}$ had significantly $(\mathrm{p}<0,05)$ lighter livers as compared to those in groups HW and HA. It was also observed that there were no significant differences in fat content of the livers (ether extract) but when the total fat quantity was considered, the larger the liver, more fat it contained, showing that the hypercholesterolaemic diet increased the fat quantity of the liver and when it was associated with aubergine extract, the increase was even higher. It is clear from the present work that the larger the liver the higher its fat amount, although the fat content was the same amongst animals of the three groups. Probably the increase in liver fat was, at least in part, responsible for the increase in the weight of this gland.

Regarding the serum levels of cholesterol and triglycerides (Table 5), the values in group $\mathrm{C}$ were lower than those in groups receiving the hypercholesterolaemic diet and this was as well expected (Autobock and Mitschek, 1974; Mitschek, 1974; Mitschek, 1975; Mitschek, 1975 ; Kritchevsky, 1975).

Table 4: Weight, ether extract and fat quantity in dried livers of animals of groups control (C), and hypercholesterolaemic plus water $(\mathrm{HW})$ or aubergine extract (HA); mean \pm standard deviation*.

\begin{tabular}{cccc}
\hline & Weight (g) & $\begin{array}{c}\text { Ether extract } \\
(\%)\end{array}$ & Fat quantity (g) \\
\hline Group C & $2,72 \pm 0,31$ a & $62,54 \pm 0,93$ a & $1,67 \pm 0,006 \mathrm{a}$ \\
Group & $4,42 \pm 1,28 \mathrm{~b}$ & $57,81 \pm 13,0 \mathrm{a}$ & $2,56 \pm 0,009 \mathrm{~b}$ \\
HW & & & \\
Group & $5,10 \pm 1,20 \mathrm{~b}$ & $61,62 \pm 6,40 \mathrm{a}$ & $3,14 \pm 0,014 \mathrm{c}$ \\
HA &
\end{tabular}

*Means followed by different letters in the same column are statistically different $(\mathrm{P}<0,05)$.

On the other hand, the animals receiving aubergine extract had higher serum cholesterol levels as compared to those being given water, although triglycerides levels were similar. A high individual variation among animals receiving the hypercholesterolaemic was observed, particularly in relation to serum triglycerides. So the most important result shown in this table is the statistically significant increase in cholesterol in group HA, even with high values of standard deviation. In the case of triglycerides, the deviation was even higher. Nevertheless, as the means in the hypercholesterolaemic groups were similar (and different from those in the control group) the finding is reinforced.

Table 5: Serum levels of cholesterol and triglycerides $(\mathrm{mg} / \mathrm{dl})$ of animals of groups control (C) and hypercholesterolaemic plus water (HW) or aubergine extract (HA); mean \pm standard deviation*.

\begin{tabular}{ccc}
\hline & $\begin{array}{c}\text { Serum } \\
\text { cholesterol }\end{array}$ & $\begin{array}{c}\text { Serum } \\
\text { triglycerides }\end{array}$ \\
\hline Group C & $53,96 \pm 5,68 \mathrm{a}$ & $143,06 \pm 19,46 \mathrm{a}$ \\
Group HW & $98,66 \pm 36,18 \mathrm{~b}$ & $216,51 \pm 76,90 \mathrm{~b}$ \\
Group HA & $199,06 \pm 74,72 \mathrm{c}$ & $235,29 \pm 106,06 \mathrm{~b}$ \\
\hline
\end{tabular}

*Means followed by different letters in the same column are statistically different $(\mathrm{P}<0,05)$

When the hepatic cholesterol and triglycerides levels were considered (Table 6), it was observed that the control group showed lower values in relation to group $\mathrm{HW}$ but not in relation to group HA, although both had similar levels of triglycerides in this gland. This indicates that aubergine extract has a positive effect in lowering liver cholesterol in rats, an effect similar to that observed in rabbits by Mitschek (1974; 1975; ).

From the results obtained in this work, it could be concluded that under the experimental conditions employed, the aubergine extract increased serum cholesterol levels and had little effect on serum triglycerides, but lowered hepatic cholesterol, although its effect on liver triglycerides was small. 
Table 6: Hepatic levels of cholesterol and triglycerides $(\mathrm{mg} / \mathrm{dl})$ of animals of groups control (C) and hypercholesterolaemic plus water (HW) or aubergine extract (HA); mean \pm standard deviaton*.

\begin{tabular}{ccc}
\hline & $\begin{array}{c}\text { Hepatic } \\
\text { cholesterol }\end{array}$ & $\begin{array}{c}\text { Hepatic } \\
\text { Triglycerides }\end{array}$ \\
\hline Group C & $242,01 \pm 79,9 \mathrm{a}$ & $698,24 \pm 104,3 \mathrm{a}$ \\
Group HW & $605,52 \pm 239,5 \mathrm{~b}$ & $1.062,20 \pm 3,6 \mathrm{~b}$ \\
Group HA & $341,38 \pm 131,6 \mathrm{a}$ & $999,30 \pm 136,4 \mathrm{~b}$ \\
\hline
\end{tabular}

*Means followed by different letters in the same column are statistically different $(\mathrm{P}<0,05)$.

\section{RESUMO}

A beringela (Solanum melongena) tem sido apontada como possuidora da capacidade de reduzir o colesterol sérico. $\mathrm{O}$ chá do vegetal vem sendo utilizado com este propósito, devido ao interesse na descoberta de formas alternativas para o controle da hipercolesterolemia. No presente trabalho testou-se o efeito do chá de beringela nos níveis séricos e hepáticos de colesterol e triglicerídeos em ratos adultos. Ratos Fisher foram divididos em três grupos: o primeiro recebeu dieta normolipídica ad libitum e água para beber, funcionando como controle; os outros dois receberam dieta hipercolesterolêmica com $30 \%$ de óleo vegetal e $1 \%$ de colesterol, sendo dada a um destes grupos água para beber, enquanto que o outro recebeu apenas chá de beringela. Após 28 dias os animais foram sacrificados e dosaram-se os níveis de colesterol e triglicerídeos séricos e hepáticos. Os resultados obtidos indicam que, nas condições experimentais utilizadas, o chá de beringela eleva o colesterol sérico, reduz $\mathrm{o}$ hepático e tem pouco ou nenhum efeito sobre os triglicerídeos, tanto séricos quanto hepáticos.

\section{REFERENCES}

Autobock, L.; Mitschek, G.H. (1974)- Effect of Solanum melongena on experimental atheromatosis. V. Electron microscopic observations on cholesterol-induced atheromatosis in rabbits in mean and longterm tests. Exp. Pathol. Jena, 9(5-6):323-335.

Cortella, A.; Pochettino, M.L.(1997) - Análisis y evaluación de los "tes" comercializados para el tratamiento del colesterol. $L a$ Alimentación Latinoamericana, 31(217): 4957.

Henry, R.J.; Cannon, D.C.; Winkelman, J.W.(1974). In- Clinical Chemistry, Principles and Technics, $2^{\text {nd }}$ ed., New York, Harper \& Row

Kayamori, F.; Igarashi, K. (1994) - Effects of dietary nasunin on the serum cholesterol level in rats. Biosci. Biotech. Biochem., 58(3): 570571.

Kritchevsky, D.; Tepper, A. S.; Story, J. A.(1975) - Influence of an eggplant (Solanum melongena) preparation on cholesterol metabolism in rats. Exp. Pathol. Jena, 10 (34): $180-183$.

Mitschek, G.H.(1974)- Effect of Solanum melongena on experimental atheromatosis. III. Histological studies in surface preparations of aortic intima of rabbits fed cholesterol in short-term test. Exp. Pathol. Jena, 9(3):157-161.

Mitschek, G.H.(1975) - Effect of Solanum melongena on experimental atheromatosis. IV. Histological studies on cholesterol induced atheromatosis in rabbits in mean and long-term tests. Exp. Pathol. Jena, 10(34):156-166.

Mitschek, G.H. (1975)- Effect of Solanum melongena on experimental atheromatosis. VI. Enzyme histochemical, physiopathological and chemical studies on cholesterol induced atheromatosis in rabbits. Exp. Pathol. Jena, 10(3-4): 167-179.

Tonks, D.B. (1970). In- Quality control in clinical laboratories, Diagnostic Reagents Division, Ontario 